\title{
WASILIJA MALINOWSKIEGO ROZWAŻANIA (NIE TYLKO) \\ O POKOJU I WOJNIE \\ (CZASOPISMO „ОСЕННИЕ ВЕЧЕРА”, 1803 r.)
}

\author{
VASILY MALINOVSKY'S THOUGHTS (NOT ONLY) \\ ON PEACE AND WAR \\ (PERIODICAL “FALL EVENINGS”, 1803)
}

\author{
MAGDALENA DĄBROWSKA
}

\begin{abstract}
The article presents the periodical "Fall Evenings" (1803) by Vasily Fedorovich Malinovsky (1765-1814) in the light of the themes (two thematic lines: political and moral), and particularly the connections (similarities and differences) with the themes of the series of sketches "A Russian in England..." and the treatise Thoughts on War and Peace.
\end{abstract}

Magdalena Dąbrowska, Uniwersytet Warszawski, Warszawa - Polska, m.dabrowska@uw.edu.pl

W czasopiśmie „Литературный вестник” w pierwszych latach XX wieku ukazał się cykl artykułów A.G. Maksimowa Opis rosyjskich wydawnictw periodycznych XIX wieku. Jeden z nich został poświęcony tygodnikowi Wasilija Fiodorowicza Malinowskiego (1765-1814) „Осенние вечера” z 1803 ro$\mathrm{ku}^{1}$, pozostając do chwili obecnej jedyną próbą jego omówienia. Badacz nie wyszedł $\mathrm{w}$ nim jednak poza charakterystykę pisma z perspektywy prasoznawczej oraz krótkie streszczenie poszczególnych pozycji, uzupełniając je obszernymi wypisami z co ważniejszych z nich i biogramem wydawcy. Wcześniej czasopismo Nikołaja Osipowa odnotowywali jedynie bibliografowie ${ }^{2}$ oraz twórcy słowników pisarzy i uczonych rosyjskich ${ }^{3}$.

Znacznie lepiej prezentuje się stan badań nad publicystyką Malinowskiego. Prace nad nią, rozpoczęte w XIX stuleciu przez W. Siemiew-

1 А.Г. М а к с и м о в, Описание русских периодических изданий ХІХ Века. "Осенние вечера" 1803 года. Еженедельное издание В.Ф. Малиновского, „Литературный вестник” 1903 , т. 5, s. 445-450.

2 Nр.: Н.М. Л и с о в с к и й, Русская периодическая печать 1703-1894 г2. (Библиография и графические таблииы), Санкт-Петербург 1895, s. 10.

${ }^{3}$ Г. Г е н н а д и, Справочныи словарь о русских писателях и ученых, умерших в XVIII и XIX столетиях, и список русских книг с 1725 по 1825 г., т. 2: (Ж-М), Берлин 1880, s. 284. 
skiego ${ }^{4}$, toczyły się przez cały czas dwutorowo, obejmując zarówno wydawanie samych tekstów, jak i przygotowanie komentarzy do nich. Taki charakter miał wybór dzieł społeczno-politycznych Malinowskiego z komentarzem E.A. Arab-Ogły ${ }^{5}$ oraz studia polskiego historyka Jerzego Skowronka o Rozważaniach o pokoju i wojnié . Traktat "o pokoju i wojnie", wydany w dwóch częściach w tym samym roku co tygodnik "Осенние вечера", stanowi główną pozycję w tej części dorobku Malinowskiego, publicysty specjalizującego się $\mathrm{w}$ tematyce międzynarodowej i stosunkach dyplomatycznych.

Celem niniejszego artykułu jest przedstawienie miejsca oraz roli czasopisma „Осенние вечера" w całokształcie spuścizny pisarza i osadzenie go w kontekście epoki. Takie postawienie sprawy oznacza konieczność wykorzystania $\mathrm{w}$ charakterze tła interpretacyjnego pozostałej części spuścizny Wasilija Malinowskiego, w większości obecnie zapomnianej.

Z zamiarem wydania czasopisma Malinowski nosił się już w końcu XVIII wieku. Pismo miało nazywać się „Пустынник”, a jego pierwszy numer miała otwierać opowieść pod takim tytułem; do jego wydania nie doszło, nie ukazała się też na łamach pisma „Осенние вечера" owa opowieść, mimo że pisarz brał pod uwagę taką możliwość7. Inny kształt od pierwotnie zamierzonego przybrał również sam tygodnik „Осенние вечеpa": $^{\prime \prime}$ planowanych dwunastu numerów (po cztery w każdym jesiennym miesiącu) wyszło zaledwie osiem. Numery nie są opatrzone datami dziennymi, ale wiadomo, że pierwszy wyszedł 26 września 1803 roku$^{8}$. Liczba pozycji tworzących poszczególne numery wynosi od jednej (numer pierwszy) do trzech (numer ósmy, zawierający szkice Swoje strony, Kara i Prawda).

4 В. С е м е в с к и й, Размышления В.Ф. Малиновского о преобразовании государственного устройства России, „Голос минувшего” 1915, № 10, s. 239-264.

5 Э.А. А р а б - О г л ы, Выдающийся русский просветитель, [w:] В.Ф. М а л и н о в с к и й, Избранные общественно-политические сочинения, ред. А.П. Белик, Москва 1958, s. 3-38.

6 Przedmiotem zainteresowania badacza stała się trzecia - najmniej znana - część traktatu Malinowskiego, nie tylko skomentowana przez niego, ale także wydobyta z rękopisu (zob. J. S k o w r o n e k, "Rozważania o pokoju i wojnie” Wasyla F. Malinowskiego, „Teki Archiwalne” 1978, cz. 17, s. 23-57) i przetłumaczona na język polski (zob. Memoriat W[Wasilija Fiodorowicza] M[alinowskiego] o narodowym samookreśleniu, jako podstawie niezawistego bytu politycznego narodów, pod tytułem „Rozważania o pokoju i wojnie”, część III. Jassy 1801 - S.-Petersburg 1803, [w:] A.J. C z a r t o r y s k i, Pamiętniki i memoriały polityczne 1776-1809, red. J. Skowronek, Warszawa 1986, s. 567-599). Por.: И.С. Д о с т ь я н, „ЕВропейская утопия” В.Ф. Малиновского, „Вопросы истории” 1979, № 6, s. 32-46.

7 Zob.: В.Ф. М а л и н о в с к и й, Избранные общественно-политические..., ор. cit., s. 165 (komentarz E.A. Arab-Ogły).

8 Ibidem, s. 159. 
Wszystkie utwory wyszły spod pióra samego Malinowskiego, co nadaje tygodnikowi cechy zbioru jednoautorskiego?.

Mimo iż wydawca nie określił żadnego tekstu mianem przedmowy, taką właśnie rolę pełni artykuł z pierwszego numeru pisma. Znajduje w nim wyjaśnienie jego tytuł oraz zostaje zasygnalizowany profil tematyczny. Daje on także wyobrażenie o stylu i tonie wypowiedzi Malinowskiego. Maksimow za wyróżniki pisma „Осенние вечера" uznał „ciężki napuszony styl i kaznodziejski ton"10; tym samym określeniem posłużyli się współcześni badacze prasy rosyjskiej ${ }^{11}$. Warto dodać, że $\mathrm{w}$ zakończeniu przedmowy Malinowski wystąpił z apelem do czytelników o przesyłanie własnych utworów; jak wiemy, apel ten nie doczekał się odzewu.

Malinowski nadał tygodnikowi taki tytuł, gdyż uznał jesienne wieczory za najlepszą porę do zagłębiania się $\mathrm{w}$ rozmyślania natury egzystencjalnej. Materiału do takich rozważań miało dostarczyć czytelnikom jego pismo. Słowami-kluczami stają się w nim dobro i zło, Bóg i wieczność, państwo i świat, wreszcie pokój i wojna. Z problemami wojny i pokoju zetknął się Malinowski w trakcie sprawowania obowiązków dyplomatycznych (nie był on zresztą jedynym pisarzem-dyplomatą w Rosji przełomu XVIII i XIX wieku12). Do użytego w tytule czasopisma określenia Malinowski wrócił $\mathrm{w}$ artykule zamieszczonym $\mathrm{w}$ drugim numerze, pytając $\mathrm{w}$ nim kobiety, czy „jesienne wieczory" nie przypominają im o krótkotrwałości życia. Przemijalność ludzkiej egzystencji oraz ład na świecie, stanowiący także przedmiot rozważań historiozoficznych, należą do najczęściej podejmowanych przez publicystę problemów.

Wszystkie pozycje w dorobku Malinowskiego i wydarzenia z jego życia są ze sobą ściśle związane. Na zawartość czasopisma „Осенние вечера" rzuca światło przede wszystkim okres „brytyjski” w jego biografii, przypadający na lata 1789-1791, ale pamiętać należy również o udziale pisarza w kongresie w Jassach w 1792 roku, kończącym wojnę rosyjsko-turecką z lat 1787-1791, oraz o okresie "mołdawskim”, trwającym w latach 1801-1802 i związanym z pełnieniem przez niego obowiązków rosyjskiego konsula generalnego w Jassach. Mimo że koleje losu Malinowskiego po roku 1803

9 Jak przypomina Walentina Bieriezina, posługiwanie się określeniem „czasopismo" $\mathrm{w}$ odniesieniu do gazety, almanachu i zbioru było na początku XX wieku zjawiskiem rozpowszechnionym; zob.: В.Г. Б е р е з и н а, Русская журналистика первой четверти ХІХ века, Ленинград 1965, s. 8.

10 А.Г. М а к с и м о в, op. cit., s. 448. Tu i dalej, o ile nie podano inaczej, przekład własny - M. D.

11 А.Г. Д е м е н т ь е в, А.В. 3 а п а д о в, М.С. Ч е р е п а х о в, Русская периодическая печать (1702-1894). Справочник, Москва 1959, s. 109.

12 Por. m.in.: Е.Н. М а р а с и н о в а, И.И. Хемницер - писатель и дипломат, [w:] XVIII век: сборник, ред. Н.Д. Кочеткова, сб. 24, Санкт-Петербург 2006, s. 219-254. 
jako niezwiązane z czasopismem „Осенние вечера" nie wchodzą w krąg zainteresowań, warto przypomnieć także, iż przez ostatnie lata życia zajmował on stanowisko dyrektora elitarnego Liceum w Carskim Siole, pierwszego w historii tej placówki. W kontekście tym Jakow Grot pisał: „Malinowski był człowiekiem oświeconym i uczciwym: w nagle osieroconym przez niego liceum [...] zaczęły się niesnaski"13.

W czasie pobytu na placówce dyplomatycznej w Londynie spod pióra Malinowskiego wyszła pierwsza część Rozważań o pokoju i wojnie. Na związek tematyczny pisma "Осенние вечера" z tym traktatem, którego druga część powstała już w Rosji, wskazują same tytuły zamieszczonych w nim pozycji. Najważniejszą z nich jest szkic $O$ wojnie, rozpoczynający się od stwierdzenia, że „Francja i Anglia naruszyły niedawno ustanowiony pokój i ich walka znów zagraża Europie wybuchem wojny powszechnej"14. O Anglii mowa jest też $\mathrm{w}$ innych tekstach zamieszczonych $\mathrm{w}$ piśmie, a także w utworach, które miały się w nim znaleźć. Do tych ostatnich należy wspomniana opowieść Pustelnik, przedstawiająca Anglię jako kraj zbytku, ale także zdrowego rozsądku i przywiązania do wartości rodzinnych ${ }^{15}$. O zainteresowaniu tematyką „angielską" świadczy wreszcie opublikowana w 1796 roku w piśmie W.S. Podszywałowa i P.A. Sochackiego „Приятное и полезное препровождение времени" seria szkiców Rosjanin w Anglii. Urywki listów pewnego podróżnika, pomyślana przez pisarza, którego autorstwo udało się ustalić dopiero niedawno ${ }^{16}$, jako kompendium wiedzy w różnych sferach życia w Anglii, od klimatu i kuchni, przez obrzędy religijne oraz kulturę, do historii oraz organizacji sądownictwa. Pobyt za granicą wyostrzył spojrzenie Malinowskiego na własny kraj: skłonił do porównywania go z obcą rzeczywistością oraz podsunął myśl o podjęciu niektórych tematów także w odniesieniu do gruntu rodzimego.

Oto jedna z obserwacji Malinowskiego na ten temat, zapisana przez niego w dzienniku:

13 Я. Г р о т, Пушкин, его мицейские товарищи и наставники, Санкт-Петербург 1887, s. 51.

14 [Б.п.], О войне, „Осенние вечера” 1803, № 2, s. 14. Wszystkie utwory zamieszczone w czasopiśmie występują bez podpisu autora. Na potrzeby niniejszej pracy został wykorzystany egzemplarz ze zbiorów Rosyjskiej Biblioteki Państwowej (Музей книги РГБ) w Moskwie (z brakującym numerem 4; jego brak odnotował wcześniej E.A. Arab-Ogły; zob.: В.Ф. М а л и н о в с к и й, Избранные общественно-политические..., ор. cit., s. 159).

15 Zob.: В.Ф. М а л и н о в с к и й, Главы из повести „Пустынник”, [w:] tegoż, Избранные общественно-политические..., ор. cit., s. 145.

16 Zob.: В. Б е с п р о з в а н н ы й, Кто был автором „Россиянина В Англии”?, [w:] В честь 70-летия профессора Ю.М. Лотмана, Тарту 1992, s. 49-56; М. D ą b r o w s k a, Dla pożytku i przyjemności. Rosyjska podróż sentymentalna przełomu XVIII i XIX wieku, Warszawa 2009, s. 181 (tamże zob. adres bibliograficzny utworu). 
Здесь в России все помышляют только о забавах и более еще ни о чем, кроме щегольства и чинов. Вчера ребенок 15-летний, воспитанный в Англии, с детскою простотою приметил мне, что здесь в больших домах, съехавшись, говорят такой вздор, что слушать нельзя - о чепцах и нарядах ${ }^{17}$.

Na podstawie tego fragmentu Siemiewski sformułował wniosek o umiejętności tworzenia przez pisarza obrazków obyczajowych z życia współczesnego społeczeństwa rosyjskiego ${ }^{18}$.

Jeśli zestawić ze sobą szkic Rosjanin w Anglii... oraz zawartość pisma "Осенние вечера", to okaże się, że można odnaleźć w nich szereg wspólnych linii tematycznych, zrodzonych pod wpływem obserwacji obcej rzeczywistości i odniesionych następnie do realiów rodzimych.

W obu snuje więc Malinowski rozważania o źródłach miłości do ojczyzny:

Из всех чувствований, из всех пристрастий, любовь отечества есть благороднейшее. Любовь к самому себе, непременно врожденная каждому человеку, есть первоначальный источник любви к отечеству ${ }^{19}$.
Приятно воспоминание родимой стороны своей! [...] Любовь к своей стороне природна человеку, поелику любовь к себе распространяется на ближайших, сходственнейших и от них уже далее идет...20 dzieli:

W jednym i drugim ocenia sposób obchodzenia przez wierzących nie-

Два раза был я в здешней [лондонской - M. D.] церкви. [...] Слушатели никакого шуму не делают. [...] Воскресенье препровождают совершенно по-христиански. Не играют ни в карты, ни танцуют, ни поют песен, и не работают. В этот день не бывает театральных увеселений и никаких зрелищ, и все лавки заперты ${ }^{21}$.
Сочти сколько базаров в городе - все полны народу, Воскресенье торговой день по всей России! [...] Кабаки начали запирать на время обедни, но торги идут своим чередом...22

${ }_{17}$ Мелочи прошлого. Черты для характеристики русского общества. [Из дневника В.Ф. Малиновского], „Голос минувшего” 1815, № 12, s. 241.

18 Ibidem (komentarz W. Siemiewskiego).

${ }^{19}$ Cyt. za: [В.Ф. М а л и н о в с к и й], Россиянин В Англии. Отрывки из писем одного путешественника, [w:] „Я берег покидал туманный Альбиона...". Русские писатеми об Англии. 1646-1945, ред. О.А. Казнина и А.Н. Николюкин, Москва 2001, s. 62 (utwór występuje $\mathrm{w}$ antologii jako anonimowy).

20 [Б.п.], Своя сторона, „Осенние вечера” 1803, № 8, s. 57.

${ }^{21}$ Cyt. za: [В.Ф. М а л и н о в с к и й], Россиянин $b$ Англии..., ор. cit., s. 56.

22 [Б.п.], Воскресенье, „Осенние вечера” 1803, № 7, s. 49-50. 
W obydwu wreszcie rozpatruje problem zdrady małżeńskiej:

Нарушение брачного ложа почитается здесь ужасным преступлением. Законы наказывают оное в людях достаточных денежным штрафом. [...] Я почитаю сии законы весьма хорошими и действительными для удержания молодых людей от своевольства ${ }^{23}$.

Szerszego komentarza wymaga artykuł Swoje strony, z którego pochodzą rozważania o miłości do ojczyzny. Napisany z perspektywy człowieka znajdującego się poza tytułową rodzinną okolicą, rzuca on światło na sposób rozumienia przez pisarza patriotyzmu: droga do miłości do ojczyzny ma korzenie $\mathrm{w}$ przywiązaniu do rodziny i prowadzi przez miłość do rodzinnej okolicy i sąsiadów; bez przejścia przez te dwa etapy - jakby patriotyzmu w skali "mikro” - nie jest możliwe osiągnięcie wartości najwyższej, patriotyzmu w skali ",makro".

Już na podstawie tych trzech przykładów można sformułować wniosek o obecności w piśmie „Осенние вечера” dwóch linii tematycznych, mianowicie politycznej (o wydźwięku patriotycznym) i etycznej (o zabarwieniu religijnym). Obie linie dają o sobie znać także w traktacie Rozważania o pokoju i wojnie, o czym świadczą jego początkowe i końcowe partie:

Довольно кратка наша жизнь и исполнена премногих неизбежных зол Должны ль мы сами оную сокращать, и ко многим бедам, неразлучным с нами по человечеству, присовокупить еще войну, которая есть зло самопроизвольное и соединение всех зол в свете. [...] Война заключает в себе все бедствия. [...] Она есть адское чудовище, которого следы повсюду означаются кровию, которому везде последует отчаяние, ужас, скорбь, болезни, бедность и смерть 25 .

Всевышний создатель мира, как отец всех человеков, так сотворил их, что они токмо в всеобщем благоденствии могут быть счастливы. Закон его есть любовь и правосудие 26.

Krąg rodaków, w którym Malinowski obracał się w Anglii, tworzyli Siemion Woroncow i pracownicy rosyjskiej placówki dyplomatycznej oraz Nikołaj Karamzin i Grigorij Demidow. "Trzech Rosjan, $\mathrm{M}^{*}, \mathrm{D}^{*}$ i ja, [...] wsiedliśmy do łódki i popłynęliśmy do Greenwich" - napisał Karamzin w Listach podróżnika rosyjskiego (list 144 „Londyn, lipca... 1790”), mając

23 Cyt. za: [В.Ф. М а л и н о в с к и й], Россиянин $b$ Англии..., op. cit., s. 66-67.

24 [Б.п.], [Когда же раздумает кто...], „Осенние вечера” 1803, № 2, s. 11.

${ }^{25}$ В.Ф. М а л и н о в с к и й, Рассуждение о мире и войне, [w:] tegoż, Избранные общественно-политические..., ор. сіt., s. 41.

${ }^{26}$ Ibidem, s. 93. 
na myśli właśnie Malinowskiego i Demidowa ${ }^{27}$. W podmiejskim domu hrabiego Woroncowa pisarz skończył pierwszą część Rozważań o pokoju i wojnie (druga powstała w należącej do teścia Malinowskiego posiadłości Biełozierka) ${ }^{28}$. Wśród znajomych pisarza bardzo dobrze znane były dyskusje nad problemem wojny i pokoju oraz prace $\mathrm{z}$ tego zakresu ${ }^{29}$. I w tym kontekście można przywołać Listy podróżnika rosyjskiego, których narrator na kolacji w Londynie wygłasza następujący toast: „za wieczny pokój i kwitnący handel!” (list 137 „Londyn, lipca... 1790”) ${ }^{30}$. Anthony Cross zauważył, iż poglądy zawarte w traktacie Malinowskiego mieszczą się „,w ogólnych ideach europejskiego Oświecenia", nie mają korzeni w żadnym konkretnym źródle angielskim, jednocześnie zaznaczając jednak, że jego autor „mógł znać Jeremy Benthama i niewykluczone, że omawiał $\mathrm{z}$ nim problemy [...] poruszone $\mathrm{w}$ przygotowanym przez Benthama Planie wiecznego i powszechnego pokoju" 31 . Jeśli o Benthamie, zaliczanym do czołowych europejskich utylitarystów, mówi się, że jego „ideałem [...], podobnie jak ideałem Epikura, było bezpieczeństwo, nie wolność"32 i że "bezpieczeństwo, będąc podstawą życia, egzystencji, obfitości, szczęścia, jest [...] ważniejsze od równości"33, to w dużym stopniu słowa te odnoszą się również do rosyjskiego publicysty.

O bezpieczeństwie jako najwyższej wartości pisał Malinowski na początku traktatu:

Лишая народы [...] безопасности [...], она [война - M. D.] рано или поздно причиняет их совершенное падение ${ }^{34}$.

Innego dowodu na szczególne wyczulenie Malinowskiego na problemy wojny i pokoju dostarczył M. Schippan w kontekście badań nad jego

27 Н.М. К а р а м $з$ и н, Письма русского путешественника, ред. Ю.М. Лотман, Н.А. Марченко, Б.А. Успенский, Ленинград 1984, s. 355.

${ }^{28} \mathrm{Na}$ miejsce napisania poszczególnych części wskazał sam Malinowski, opatrując każdą z nich stosowną adnotacją. Por. także: Сочинения Державина с объяснительными примечаниями Я. Грота, т. 6 (Переписка 1794-1816 и „Записки”), Санкт-Петербург 1871, s. 238 (postscriptum do listu Malinowskiego opatrzonego nagłówkiem „Carskie Sioło, 4 sierpnia $\left.1812^{\prime \prime}\right)$.

29 Zob. o tym w odniesieniu do Karamzina: Ю.М. Л о т м а н, Сотворение Карамзина, [w:] tegoż, Карамзин. Сотворение Карамзина. Статьи и исследования 1957-1990. Заметки и рецензии, Санкт-Петербург 1997, s. 182.

${ }^{30}$ H.M. K а р а м 3 и н, op. cit., s. 338.

31 Э. К р о с с, У Темзских берегов. Россияне в Британии в XVIII веке, пер. Н.Л. Лужецкая, Санкт-Петербург 1996, s. 47.

32 B. R u s s e l, Dzieje filozofii Zachodu i jej związki z rzeczywistościa polityczno-społeczna od czasów najdawniejszych do dnia dzisiejszego, tł. T. Baszniak, A. Lipszyc i M. Szczubiałka, Warszawa 2000, s. 877.

${ }_{33}^{3}$ T. T u l e j s k i, Od zasady użyteczności do demokracji. Filozofia polityczna Jeremy Benthama, Łódź 2004, s. 136.

34 В.Ф. М а л и н о в с к и й, Рассуждение..., ор. cit., s. 41. 
działalnością przekładową: na początku 1804 roku Malinowski przetłumaczył fragmenty powieści J.G. Junga-Stillinga Theobald, albo Marzyciele (Theobald, oder die Schwärmer), zawierającej wypady przeciwko wojnie ${ }^{35}$. $\mathrm{W}$ sposób szczególny rosyjskiego pisarza zainteresowały otwierające ten utwór rozważania historyczne oraz rozważania o charakterze moralno-religijnym z jego dalszych partii ${ }^{36}$.

Wymowa Rozważań o pokoju i wojnie oraz poświęconych tym kwestiom pozycji z pisma „Осенние вечера”, przede wszystkim artykułu O wojnie, w ogólnych zarysach pokrywają się ze sobą: jawią się jako głos protestu przeciwko wojnie oraz apel o pokój. O opublikowanych częściach rozprawy Jerzy Skowronek pisał, że Malinowski poddawał w nich "gruntownej, wielostronnej krytyce zasady i praktyki dyplomacji i całej polityki zewnętrznej od starożytności do współczesności, widząc w nich jeden z głównych elementów, a zarazem źródło zła, nieszczęść i niesprawiedliwości [...]; dużo miejsca poświęcił dowodzeniu fundamentalnej tezy, iż wojny i podboje obcych ziem służyły wyłącznie korzyściom władców lub uprzywilejowanych warstw mających udział w rządzeniu, a nigdy nie przyniosły pożytku rozwojowi ludzkości, czy choćby narodom lub państwom zwycięskim" 37 . Między traktatem a zawartością czasopisma jest jednak również istotna różnica: jeżeli w traktacie przeważają rozważania o charakterze ogólnym, to pismo opiera się na konkretach, opisach europejskich realiów geopolitycznych i ekonomicznych. Skowronek pisał o Malinowskim jako wydawcy tygodnika „Осенние вечера": „na jego łamach [...] ogłosił kilka artykułów wyjaśniających konieczność zainicjowania przez Rosję bardziej aktywnej polityki celem ograniczenia francuskiej dominacji na kontynencie"38. I jeszcze opinia Anthony Crossa na ten temat: „W czasopiśmie kontynuował on [...] propagowanie pokoju $\mathrm{w}$ serii wnikliwych artykułów o ówczesnej sytuacji w Europie, przede wszystkim o konflikcie między Francją i Anglią"39.

Wymienioną różnicę dobrze obrazują rozważania o zgubnym wpływie wojny na handel:

Торговля и рукоделия, ободряемые с толиким рачением, приходят от войны в упадок ${ }^{40}$.
Бедный Гамбург, богатый город, соперник голландской торговли, будет ли как Данциг? Сей также процветал в свое

${ }^{35}$ М. Ш и п п а н, В.Ф. Малиновский - переводиик фрагмента романа "Теобальд, или Мечтатели” И.Г. Юнга-Штилиинга, „XVIII век”, сб. 22, ред. Н.Д. Кочеткова, s. 310-319.

36 Ibidem, s. 315.

${ }^{37} \mathrm{~J}$. S k o w r o n e k, op. cit., s. 26-27; Por. przypis 6.

38 Ibidem, s. 25.

39 Э. K p o c c, op. cit., s. 47.

40 В.Ф. М а л и н о в с к и й, Рассуждение..., ор. cit., s. 59. 
время. Остановка кораблеплавания и всего торгу, лишает работы и дневного пропитания тысячи семейств, и богатые купцы в общей опасности банкрутства! ${ }^{1}$

Wspominając na początku artykułu $O$ wojnie o naruszeniu pokoju przez Francję i Anglię, Malinowski miał na myśli pokój w Amiens z 25 marca 1802 roku. Za tło interpretacyjne służyły mu wcześniejsze ugody (pokój w Lunéville z 9 lutego 1801 roku), a także działalność polityków europejskich (premiera brytyjskiego Williama Pitta Młodszego, po raz pierwszy pełniącego tę funkcję w latach 1783-1801). Z artykułu wyłania się obraz wojny, która ogarnęła swoim zasięgiem większą część Europy, ląd i morza. „Francja i Anglia są jedynymi walczącymi państwami, a Europa cierpi z powodu ich sporu, jedni zajęli przystanie od strony lądu, drudzy nacierają na nie od morza" - pisze autor ${ }^{42}$. Podobny wydźwięk mają rozważania o Malcie i Lampedusie: „te dwie wysepki, które przyczyniły się do utraty ciszy i spokoju w Europie, są ważne nie same w sobie, lecz ze względu na swoje położenie na Morzu Śródziemnym i obecność tam floty" ${ }^{43}$. Aby podkreślić grozę sytuacji, rosyjski publicysta posłużył się powszechnie kojarzonymi porównaniami do Troi oraz Sodomy i Gomory.

W następnych artykułach pisarz zarzuca tematykę europejską i przechodzi do rosyjskiej, nie tyle jednak zagłębiając się w sytuację polityczną i działania polityków, ile przekonując czytelników do podjęcia określonej postawy wobec kraju. Jak wygląda droga do patriotyzmu odpowiedział, jak wiemy, w szkicu Moje strony. W artykule Historia Rosji zwrócił uwagę na potrzebę studiowania dawnych kronik, ważną w szczególności wobec braku, jak zauważa, „dobrej całościowej historii ojczyzny” 44. Przewagę latopisów nad nawet najlepszymi zarysami dziejów Malinowski upatruje w tym, że odzwierciedlają one sposób postrzegania świata swoich czasów, podczas gdy stworzone współcześnie opracowanie jest świadectwem właśnie współczesności, choć dotyczy przeszłości. Główną część tego artykułu wypełnia opis zawojowania Rusi przez Tatarów, zaczerpnięty z Księgi stopni rodowodu carskiego (według ustaleń Arab-Ogły, z wydania G.F. Millera z 1775 roku $^{45}$ ). Temat przewodni artykułu Miłość do Rosji stanowi rozległość terytorialna państwa rosyjskiego i związana z nią różnorodność klimatyczna i językowa. „Główną troską winno być zespolenie wszystkich w miłości

41 [Б.п.], О войне..., ор. cit., s. 18.

42 Ibidem, s. 17.

43 Ibidem, s. 16.

44 [Б.п.], История России, „Осенние вечера" 1803, № 6, s. 41.

45 Zob.: В.Ф. М а л и н о в с к и й, Избранные общественно-политические..., ор. cit., s. 160 (komentarz E.A. Arab-Ogły). 
i zgodzie" - pisze Malinowski46, a słowa "miłość i zgoda” brzmią jak refren całego artykułu.

Na zakończenie warto podjąć próbę określenia przynależności tygodnika „Осенние вечера" do typu wydawnictw periodycznych czasów Oświecenia. Z dwóch głównych typów wyróżnionych przez Jerzego Łojka - „czasopism moralnych”, wypełnionych "rozważaniami na temat rozmaitych aspektów natury ludzkiej, obyczajowości społeczeństwa, wzorów postępowania i wskazań życiowych o wyższej społecznej wartości", oraz "czasopism zbiorowych", zamieszczających "materiały informacyjne i literackie, rozprawy, recenzje, ciekawostki historyczne, geograficzne, przyrodnicze, $[\ldots]$ artykuły na aktualne tematy polityczne" 47 - periodyk Malinowskiego wydaje się bliższy pierwszemu z nich. Jeśli chodzi zaś o „czasopisma zbiorowe", to w artykule Swoje strony wskazywał on na ich brak w Rosji: kraj ten - "tak wielki jak cała Europa" - nie doczekał się dotąd "gazety, która by opisywała wszystkie ważne wydarzenia i która by obwieszczała w Jekatierinosławiu, jak żyje się w Kazaniu"; taki stan rzeczy nie sprzyja, zdaniem publicysty, wspominanej integracji obywateli, żyjących na ogromnej przestrzeni jak ludzie sobie obcy ${ }^{48}$. W Rozważaniach o pokoju i wojnie Malinowski skarżył się natomiast na redaktorów gazet, którym - jako tym, którzy mają przekazywać nowe informacje - zdarza się świadczyć nieprawdę i ulegać naciskom możnych.

\section{Bibliografia}

А р а б - О г лы Э.А., Выдающийся русский просветитель, [w:] В.Ф. М а л и н о в с к и й, Избранные общественно-политические сочинения, ред. А.П. Белик, Москва 1958, s. 3-38.

Б е р е з и н а В.Г., Русская журналистика первой четверти ХІХ века, Ленинград 1965.

Б е с п р о з в а н н ый В., Кто был автором „Россиянина В Англии”?, [w:] В честь 70-летия профессора Ю.М. Лотмана, Тарту 1992, s. 49-56.

[Б.п.], Воскресенъе, „Осенние вечера" 1803, № 7, s. 49-50.

Г е н н а д и Г., Справочный словарь о русских писателях и ученых, умерших в XVIII и ХІХ столетиях, и список русских книг с 1725 по 1825 г., т. 2: (Ж-М), Берлин 1880.

Г р о т Я., Пушкин, его лицейские товарищи и наставники, Санкт-Петербург 1887.

Д е м е н т ь е в А.Г., 3 а п а д о в А.В., Ч е р е п а х о в М.С., Русская периодическая печать (1702-1894). Справочник, Москва 1959.

Д о с т ь я н И.С., „ЕВропейская утопия” В.Ф. Малиновского, „Вопросы истории” 1979, № 6, s. 32-46.

46 [Б.п.], Любовъ России, „Осенние вечера” 1803, № 5, s. 36.

47 J. Ł o j e k, Zarys historii prasy polskiej w latach 1661-1831, Warszawa 1972, s. 50.

48 [Б.п.], Своя сторона..., ор. cit., s. 60-61. 
[Б.п.], История России, „Осенние вечера" 1803, № 6, s. 41.

К а р а м 3 и н Н.М., Письма русского путешественника, ред. Ю.М. Лотман, Н.А. Марченко, Б.А. Успенский, Ленинград 1984.

[Б.п.], [Когда же раздумает кто...], „Осенние вечера” 1803, № 2, s. 11.

К р о с с Э., У Темзских берегов. Россияне в Британии в XVIII веке, пер. Н.Л. Лужецкая, Санкт-Петербург 1996.

Л и с о в с к и й Н.М., Русская периодическая печать 1703-1894 гг. (Библиография и графические таблицы), Санкт-Петербург 1895.

Л о т м а н Ю.М., Карамзин. Сотворение Карамзина. Статьи и исследования 1957-1990. Заметки и реиензии, Санкт-Петербург 1997.

Л о т м а н Ю.М., Сотворение Карамзина, [w:] tegoż, Карамзин. Сотворение Карамзина. Статьи и исследования 1957-1990. Заметки и рецензии, Санкт-Петербург 1997, s. 182.

М а к с и м о в А.Г., Описание русских периодических изданий ХІХ века. "Осенние вечера" 1803 года. Еженедельное издание В.Ф. Малиновского, "Литературный вестник” 1903 , т. 5, s. $445-450$.

М а л и н о в с к и й В.Ф., Рассуждение о мире и войне, [w:] tegoż, Избранные общественно-политические..., ор. cit., s. 41.

[М а л и н о в с к и й В.Ф.], Россиянин В Англии. ОтрыВки из писем одного путешестВенника, [w:] "Я берег покидал туманный Альбиона...". Русские писатели об Англии. 1646-1945, ред. О.А. Казнина и А.Н. Николюкин, Москва 2001, s. 62 (utwór występuje w antologii jako anonimowy).

М а р а с и н о в а Е.Н., И.И. Хемницер - писатель и дипломат, [w:] ХVIII век: сборник, ред. Н.Д. Кочеткова, сб. 24, Санкт-Петербург 2006.

Мелочи прошлого. Черты для характеристики русского общества. [Из дневника В.Ф. Маииновского], „Голос минувшего” 1815, № 12, s. 241.

[Б.п.], О войне, „Осенние вечера" 1803, № 2, s. 14.

[Б.п.], Своя сторона, „Осенние вечера” 1803, № 8, s. 57.

С е м е в с к и й В., Размышления В.Ф. Малиновского о преобразовании государственного устройства России, „Голос минувшего” 1915, № 10, s. 239-264.

Сочинения Державина с объяснительными примечаниями Я. Грота, т. 6 (Переписка 17941816 и „Записки”), Санкт-Петербург 1871, s. 238 (postscriptum do listu Malinowskiego opatrzonego nagłówkiem "Carskie Sioło, 4 sierpnia 1812").

Ш и п п а н М., В.Ф. Малиновский - переводиик фрагмента романа „Теобальд, или Мечтатели” И.Г. Юнга-Штиллинга, „XVIII век”, сб. 22, ред. Н.Д. Кочеткова, s. 310-319.

"Я берег покидал туманный Альбиона...". Русские писатели об Англии. 1646-1945, ред. О.А. Казнина и А.Н. Николюкин, Москва 2001.

C z a r t o r y s k i A.J., Pamiętniki i memoriaty polityczne 1776-1809, red. J. Skowronek, Warszawa 1986.

D ą b r o w s k a M., Dla pożytku i przyjemności. Rosyjska podróż sentymentalna przełomu XVIII i XIX wieku, Warszawa 2009. 
Ł o j e k J., Zarys historii prasy polskiej w latach 1661-1831, Warszawa 1972.

R u s s e 1 B., Dzieje filozofii Zachodu i jej związki z rzeczywistościa polityczno-społeczna od czasów najdawniejszych do dnia dzisiejszego, tł. T. Baszniak, A. Lipszyc i M. Szczubiałka, Warszawa 2000.

S k o w r o n e k J., "Rozważania o pokoju i wojnie” Wasyla F. Malinowskiego, „Teki Archiwalne" 1978 , cz. 17, s. 23-57.

T u l e j s k i T., Od zasady użyteczności do demokracji. Filozofia polityczna Jeremy Benthama, Łódź 2004. 